\title{
Sustainable Development Strategy through GRI with Reference to VEDANTA Company
}

\author{
Meghana Salins ${ }^{1}$, Sujaya H. ${ }^{1}$, \& P. S. Aithal ${ }^{2}$
}

${ }^{1}$ Research Scholar, College of Management \& Commerce, Srinivas University, Mangalore,

${ }^{2}$ College of Management \& Commerce, Srinivas University, Mangalore, India

E-mail: meghana.salins95@gmail.com

Type of the Paper: Explorative Research.

Type of Review: Peer Reviewed.

Indexed In: OpenAIRE.

DOI: http://doi.org/10.5281/zenodo.2918752.

Google Scholar Citation: IJCSBE

\section{How to Cite this Paper:}

Meghana, S., Sujaya, H., \& Aithal, P. S. (2019). Sustainable Development Strategy through GRI with Reference to VEDANTA Company. International Journal of Case Studies in Business, IT, and Education (IJCSBE), 3(1), 48-55.

DOI: http://doi.org/10.5281/zenodo.2918752.

International Journal of Case Studies in Business, IT and Education (IJCSBE)

A Refereed International Journal of Srinivas University, India.

IFSIJ Journal Impact Factor for 2019-20 = 4.252

(C) With Authors.

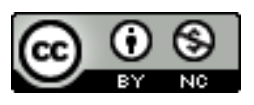

This work is licensed under a Creative Commons Attribution-Non Commercial 4.0 International License subject to proper citation to the publication source of the work.

Disclaimer: The scholarly papers as reviewed and published by the Srinivas Publications (S.P.), India are the views and opinions of their respective authors and are not the views or opinions of the S.P. The S.P. disclaims of any harm or loss caused due to the published content to any party. 


\title{
Sustainable Development Strategy through GRI with Reference to VEDANTA Company
}

\author{
Meghana Salins ${ }^{1}$, Sujaya H. ${ }^{1}$, \& P. S. Aithal $^{2}$ \\ ${ }^{1}$ Research Scholar, College of Management \& Commerce, Srinivas University, \\ Mangalore, India \\ ${ }^{2}$ College of Management \& Commerce, Srinivas University, Mangalore, India \\ Email: meghana.salins95@gmail.com
}

\begin{abstract}
Sustainable development has become one of the key principles for succeeding human development goals while at the same time strengthening the power of natural systems in order to provide ecosystem services which the economy and society depends upon. The society's end result is where the use of resources and the living conditions prolong to meet the human needs without hindering the balance of the natural systems. If ever focusing on Environmental sustainability, it will have a concern with the natural environment and how it remains diverse and productive. For natural resources are derived from the environment, the state of water, air, soil are of particular concern. GRI (Global Reporting Initiative) has an important role to form a framework of sustainable development in businesses, government and other organizations. The goal of the sustainable development process is to achieve the status of 'sustainability' in all communities. It is important to make compatible with developed and flexible using the standards laid down by GRI therefore in the long term, strategies' of sustainable development should assist the continuance of the system of biodiversity of city and suburbs through the active protection and sustainable utilization of natural sources. Therefore in order to achieve sustainability, it is necessary to make structural reforms as regarded in the standards set by GRI and to create some deep and fundamental changes in all levels of communities. Sustainable Business Models (SBM) integrates a triple bottom line approach and includes stakeholder interests, including the environment and society. They are important in implementing business innovation for sustainability and can help fix sustainability into corporate purpose, and serve as a key driver of competitive advantage. This study focuses on the analysis of the sustainable development of Vedanta Company.
\end{abstract}

Keywords: Vedanta, GRI reporting, sustainability development, Environmental concerns, triple bottom line

\section{INTRODUCTION :}

Case study in the form of industry analysis [1] or company analysis [2-3] allows researchers to analyse innovative practices and strategies followed by companies in a given industry sector and provides an opportunity to business practitioners to learn from decisions which led to success and failure in organizational performance [4]. In this case study, we made an attempt to analyse the sustainable development strategy of an Indian diversified business company named Vedanta. Formerly, Vedanta Company was known as Sesa Sterlite/Sesa Goa Limited. It is one of the world's largest diversified natural resource majors in zinc, oil and gas, iron ore, lead, silver, copper, commercial power, and aluminium. Its main operations are based in Goa, Tamil Nadu, Karnataka, Chhattisgarh, Odisha, Rajasthan, Punjab, Gujarat and Andhra Pradesh. Vedanta Company's ultimate aim is to set and achieve sustainability targets by integrating the talent of the trending generations and get the experience of the knowledge anchors across the globe [5]. They believe upon the 3 imperatives that govern their business concern that goes with collaboration, conversation, and creation of shared 
value with the intention of working collectively will give a great desired outcome. Vedanta is availing the highest scoring handed by Sustainable Plus which is the country's first label of sustainability introduced by CII-ITC Centre of Excellence for Sustainable Development (CESD) [6]. The company has been graded one among the 10 companies of sustainability and has been recognised with 'Platinum Label'. It has its existence across India, South Africa, Namibia, Australia, and Ireland with a strong focus on health, safety, and environment, and on enhancing the lives of local communities [7]. The CESD assigns businesses based on the concepts which include transparency, responsibility and accountability. They have enhanced their strengths and enlaced all sides of the triple bottom line to a build strong comprehensive extension.

\section{OBJECTIVES OF THE STUDY :}

1. To explore the concept of sustainable development in Vedanta Company.

2. To investigate the GRI reports.

3. To analyse the business areas for which Vedanta is working for.

4. To study its contribution to the environmental sustainability.

\section{RESEARCH METHODOLOGY :}

This paper discusses the principles and concepts of sustainable development. This case study is developed on the basis of secondary data. Published sources of sustainable development are taken into consideration for the analysis of the data.

\section{PROBLEM OF THE STUDY :}

An urgent need is required to know about sustainability reporting. Since it's a new concept incorporated in recent past many organizations are unaware of the benefits GRI, Sustainability development report would provide for the organization as well as the environment.

(1) To make know how Global Reporting Initiative and how GRI standards will make easier for companies to report non-financial information.

(2) To analyse how economic sustainability will help in the flourishing long-lasting structure of trade and making sure that these which structure would have less effect on environment.

(3) To know how the company would focus on the social and environmental impact of corporate actions.

(4) To study about the benefits of reporting by the organizations and how it would benefit internally and externally in terms of increased understanding of risks and opportunities and in terms of improving the goodwill of the business, avoiding the negative environment, and social environment impacts respectively.

\section{SCOPE OF THE STUDY :}

Decades ago some of the western countries had one structure of energy sources wherein these countries had to depend on one source like crude oil. Without proper measures the industries had resulted in oil catastrophe, wherein it lead to damage to the water bodies. The companies had to adapt a policy relating to its sustainability measures in order to ensure environment harmony [8]. This can happen not because of the lack of potential for the application of new technologies to developing the societal needs, but more because of the structure of economic and political power influencing the technological innovation [9]. Vedanta Limited is an exploration and production industry in minerals, oil and gas which primarily holds importance on sustainable development as their main strategy. It gives major importance to the health, safety, and environment and on improving the local communities. This company being India's only diversified natural resources company has acquired the GRI-G4 reporting for sustainable development which thereby helps to transparently communicate to the stakeholders. Since 2012, the CII-ITC Centre of Excellence of Sustainable Development has been involved with the capacity building of several units of Vedanta Company. In implementing its sustainability framework, the capacity building has led the company successfully reporting their initiatives using their international GRI-G4 guidelines. This study showcases that sustainability will involve long-lasting systems of trade and long term effect on industry and manufacture to the people working in business by ensuring that these systems do not impact the environment. An effective 
sustainability reporting cycle has varied benefits, which involves a regular program of data collection, communication, and responses. Therefore, it is high time that environmentalists and development activists must come together under the banner of sustainable development to tackle the myriad of problems facing us today [10]. With this initiative, it should help all reporting organizations, both internally and externally.

\section{ANALYSIS/RESULTS :}

The sustainable development system has fixed in the deep beliefs of Vedanta. The company's sustainable development journey carries on having extensive value for inclusion of stakeholder's interests. They have invested their time and effort in scrutinizing their actions. They have achieved their targets and formulated new ones by acquiring global best practices and taking innovative leads.

\section{Some of the initiatives taken by Vedanta are:}

(1) Water: In mining, water becomes a very critical component and obtaining supply of adequate water becomes a key challenge for this sector.

\section{Approach:}

- Vedanta has initiated to reuse water as much as possible in order to avoid and reduce the consumption of freshwater in the process focusing to minimise their water footprint.

- Vedanta's units such as HZL and Cairn India have met $66 \%$ and $36 \%$ of their total water requirement through recent water.

To further support the better management of water, Vedanta has rolled out a revised Water management performance standard.

Table 1: Water Performance Dashboard

\begin{tabular}{|l|c|l|l|}
\hline Year (F.Y) & $\begin{array}{c}\text { Total } \\
\text { Consumption (L) }\end{array}$ & $\begin{array}{c}\text { Water Water Recycled } \\
\text { Water Recycled/Reused (L) }\end{array}$ \\
\hline $2017-18$ & $280,016,308$ & $26.6 \%$ & $74,400,437$ \\
\hline $2016-17$ & $277,609,052$ & $24 \%$ & $66,813,316$ \\
\hline $2015-18$ & $236,833,021$ & $22.6 \%$ & $53,626,679$ \\
\hline
\end{tabular}

(2) Energy and Emissions: Climate change is causing a threat to the whole world. Vedanta tries to fight climatic change and goes for implementing advanced technologies that give environmental balance without effecting on the growth of the economy.

Approach:

- Vedanta Company being the part of energy industry, the energy consumption is in the order of $405 \mathrm{mn}$ GJ. This is said to be higher production and commissioning of units of Smelter and Power Plants. However, Vedanta's energy consumption per unit per production has put forth a balanced trend altogether.

To further support the better management of energy and carbon, Vedanta has rolled out a revised Energy and Emissions Performance Standard.

Table 2(a): Emissions Performance Dashboard (in tons CO equivalent)

\begin{tabular}{|l|l|l|l|}
\hline Year (F.Y) & Scope 1 (Direct) & Scope 2(Indirect) & Total \\
\hline $2017-18$ & $51,142,511$ & $1,202,076$ & $52,344,587$ \\
\hline $2016-17$ & $51,896,907$ & $1,432,665$ & $53,329,572$ \\
\hline $2015-16$ & $39,581,088$ & $1,567,606$ & $41,148,693$ \\
\hline
\end{tabular}

*The calculation report of Vedanta of Greenhouse Gas (GHG) which is parted into Scope 1 and Scope 2 where Scope 1 is for the different emissions, Scope 2 is for the electricity that is purchased. This is defined under the (WBCSD) which is World Business Council for Sustainable Development and World Resource Institute Protocol. 
Table 2(b): Energy Consumption Performance Dashboard(In million GJ)

\begin{tabular}{|l|l|l|l|}
\hline Year (F.Y) & Direct & Indirect & Total \\
\hline $2017-18$ & 425.5 & 21.12 & 466.62 \\
\hline $2016-17$ & 413.39 & 14.61 & 428 \\
\hline $2015-16$ & 394 & 11 & 405 \\
\hline
\end{tabular}

(3) Bio-Diversity: The impacts of Bio-Diversity processes is large to rivalry the impacts of many other global drivers of environmental change.

Approach:

- Vedanta Limited is a signatory to bio-diversity initiative. Their initiative in Indian sustainable standard is conforming with international management standards like IFC and ICMM (International Council of Mining and Metals). They endeavour to achieve common goal of improving mining's contribution to sustainable development. They also strive to achieve net positive gain (NPG) and avoid net loss (Net Loss) for projects located in natural habitat area. Their bio-diversity plan of their Black Mountain Mine (BMM) has been appraised by IUCN (International Union for Conservation of Nature) for the sustainable use of natural resources.

Vedanta Company has come up with some of the initiatives given below and has proceeded to establish Biodiversity Action Plans across systems during the year 2017 [11].

1. TSPL (Talwandi Sabo Power Limited), Punjab: Under the initiatives of Biodiversity Action Plans, Vedanta Company have emerged proper green belts all around the TSPL unit in order to supervise the air contamination, as well as to provide shelter to the animals and upgrade biodiversity.

2. HZL (Hindustan Zinc Limited): In Vedanta Company has taken initiative to plant trees at the project site of Rampura Agucha mine, which is the largest zinc mine in the world. In the year of 2017, Vedanta Company has planted over more than 26,000 trees under the Action Plan.

3. BALCO (Bharat Aluminium Company Limited): Under the Biodiversity Action Plan, Vedanta has initiated Medicinal Garden development in Manipat. Also, there is a provision for bird nest in and around the suburb of their business function. Their target to attain the plan was on March 2018.

4. The STERLITE COPPER: Vedanta has conducted a baseline assessment study using the Integrated Biodiversity Assessment Tool and has sketched out plans and has put forth the said initiatives for the year 2016-2017.

$>$ Conservation of indigenous agricultural gene pools.

$>$ Off-site and in-site conservation of rare species of plants, medicinal plants.

$>$ Protection of human health through prevention of diseases like malaria.

$>$ Enhancement of fisheries in streams, rivers, dams etc.

5. RESPONDING CAUTIOUSLY TO RISK OF BIODIVERSITY: The Gamsberg mine is located in South Africa which is one among of the four hotspots in the region and is among of the world's 35 hotspots. The Gamsberg area is a shelter to flora and fauna, where more than 6,000 species of plants, 260 birds, 85 mammals and 32 reptile and amphibian species exist. However, the mine targets to secure high economic returns, Vedanta Company has taken several measures to make sure that it will not affect the bio diversity [12].

> To supervise and guide the construction unit, EMP which is the Environmental Management Programme and BMP (Biodiversity Management Plan) are used so that the company abides to the environmental footmark.

$>$ During the recovery of the mine varied plant species will be used from the Succulent Karoo biodiversity hotspot of South Africa.

(4) Air Quality: Ecological Damage may happen when hazardous air pollutants come into direct contact with plant species or when animals inhale them. The impact of poor air quality on human health and the environment can wreak havoc on the economic impacts [13].

Approach: 
- Vedanta's standard of environmental management pledges their operations to check emissions to air from point as well as from process activities which is linked by energy combustion and material storage. They supervise pollutants from the emissions such as, SOx (Sulphur Oxides) and NOx (Nitrogen Oxides) as a part of their monitoring process. They also monitor fluoride emissions in their copper and aluminium operations, lead and zinc operations, and Polycyclic Aromatic Hydrocarbons in their aluminium operations.

Table 3: Emission Dashboard

\begin{tabular}{|l|l|l|l|}
\hline Year (F.Y) & Particulate Matter & SOx & NOx \\
\hline $2017-18$ & 8,837 & 191,751 & 56,853 \\
\hline $2016-17$ & $11,056^{*}$ & 178,324 & 44,935 \\
\hline $2015-16$ & $7,239^{*}$ & 157,484 & 49,464 \\
\hline
\end{tabular}

*Numbers have minor variations from those reported in the Annual Report 2017-2018

(5) Waste: Their waste includes hazardous and non-hazardous waste. Hazardous waste includes used oil, residual sludge from smelters, waste refectories, and spent pot lining. Non-hazardous waste generated includes slag, lime brit, ash, red mud, and phosphor gypsum [14].

\section{Approach:}

- Vedanta has recycled / reused 50\% of waste which is non-hazardous and has stored hazardous waste in secured land fill and sold to unauthorised recyclers.

- Vedanta Company has achieved strong operational performance in the production of copper cathodes, aluminium, power, and Zinc. They started to boost up their capacities at Aluminium and Iron Ore, and operationalised their entire power portfolio of $9000 \mathrm{MW}$.

Table 4 (a): Waste Performance Dashboard(in million MT)

\begin{tabular}{|l|l|l|}
\hline Year (F.Y) & Waste-High volume and low effect & Hazardous Waste \\
\hline $2017-18$ & 16.66 & 0.40 \\
\hline $2016-17$ & 16.57 & 0.32 \\
\hline $2015-16$ & 11.90 & 0.86 \\
\hline
\end{tabular}

Table 4 (b): High-Volume and Low-effect Waste Management(in million MT)

\begin{tabular}{|l|l|l|l|}
\hline Waste & Generated & Recycled & Percentage (\%) \\
\hline Fly Ash & 11.88 & 10.70 & $90 \%$ \\
\hline Slag & 1.43 & 1.56 & $109 \%$ \\
\hline Red Mud & 1.69 & 0.24 & $14 \%$ \\
\hline Gypsum & 1.12 & 1.17 & $104 \%$ \\
\hline Jarosite & 0.53 & 0 & $0 \%$ \\
\hline Total & 16.66 & 13.67 & $82 \%$ \\
\hline
\end{tabular}

*Includes recycling of legacy waste

\section{SUGGESTIONS/RECOMMENDATIONS :}

(1) The Sustainability Development Committee should proceed to make sure that companies which are working under it should take a balanced approach to develop sustainable development. The subsidiary companies must integrate with international best practices by monitoring its performance, lesson learning, and distribution of best practices [15].

(2) Due to the release of harmful effluents from the Sterlite Copper industry, it leads to loss of life and environmental damage and thereby resulted in violent protests against the sector. For this, the company must essentially to have an independent agency to monitor the harmful effluents which are hazardous to the environment and also the community's health. 
(3) Vedanta Company should have transparency to perusal by any independent technical committee either from the same country or from any part of the world. It should be able to prove that the industry is one among the best smelters in the world having the standardised environmental practices as they seek for zero harm, zero waste policy, and zero discharge.

\section{CONCLUSION :}

The economic growth in India is changing tremendously day by day. With 1.3 billion people and the most populous democracy in the world, India holds wealth in the possession of human and natural resources. Vedanta Company has an important role to play in making sure that the country is able to take advantage from these resources and become self-sufficient in energy supply. India spends a remarkable proportion of its foreign exchange on oil imports. Therefore, the local resources companies including Vedanta can help repair any balance that is pending. By making effective use of water consumption, increasing energy productivity, safeguarding bio-diversity or recycling waste, Vedanta Company has systems and guidelines to ensure that Vedanta makes the maximum positive impact to achieve Zero-harm to the environment.

\section{REFERENCES :}

[1] Aithal, P. S., (2017). Industry Analysis - The First Step in Business Management Scholarly Research. International Journal of Case Studies in Business, IT and Education (IJCSBE), 1(1), 1-13. DOI: http://dx.doi.org/10.5281/zenodo.810347.

[2] Aithal, P. S. (2017). An Effective Method of Developing Business Case Studies based on Company Analysis. International Journal of Engineering Research and Modern Education (IJERME), 2(1), 16-27. DOI: http://dx.doi.org/10.5281/zenodo.400579.

[3] Aithal, P. S. (2017). Company Analysis - The Beginning Step for Scholarly Research. International Journal of Case Studies in Business, IT and Education (IJCSBE), 1(1), 1-18. DOI: http://dx.doi.org/10.5281/zenodo.573769.

[4] Aithal, P. S. (2017). ABCD Analysis as Research Methodology in Company Case Studies. International Journal of Management, Technology, and Social Sciences (IJMTS), 2(2), 40-54. DOI: http://dx.doi.org/10.5281/zenodo.891621.

[5] Cairnindia.com. (2019). Media Kit. [online] Available at: https://www.cairnindia.com/Pages/MediaKit.aspx [Accessed 16 May 2019].

[6] Vedantaresources.com. (2019). Available at: https//www.vedantaresources.com/ SustainabilityDocs/ScottWilson_Jun2013.pdf [Accessed 10 May 2019].

[7] Sustainable development (2019). [online] Available at : https://www.sustainabledevelopment.in/ uploads/pdf/145061259210Years\%20of\%20CESD.pdf [Accessed 16 May 2019].

[8] Chun-juan Wang, Xiao Han, Su Xin, Da-hai Liu, Meng X, Jian-qiu Ma \& Ying Yu.(2019). An Empirical Analysis of Denmark's Energy Economy and Environment and Its Sustainable Development Policy. Journal of Sustainable Development, 12(2), 29-38.

[9] Butlin, J. (1989). Our common future. By World commission on environment and development. Journal of International Development, 1(2), 284-287.

[10] Lélé, S. (1991). Sustainable development: A critical review. World Development, 19(6), 607-621.

[11] Planningcommission.nic.in. (2019).[online] Available at: http://planningcommission.nic.in /reports/sereport/ser/isid mining\%20 report1206.pdf[Accessed 16 May 2019].

[12] Vedanta-zincinternational.com. (2019). [online] Available at: https://www.vedantazincinternational.com/component/jdownloads/send/7-2016/5-building-a-new-zinc-mine-in-abiodiveristy-hotspot [Accessed 16 May 2019]. 
[13] Balali-Mood, M., Ghorani-Azam, A. and Riahi-Zanjani, B. (2016). Effects of air pollution on human health and practical measures for prevention in Iran. Journal of Research in Medical Sciences, 21(1), 65.

[14] Bennett, G. (1990). Land disposal of hazardous waste: Engineering and environmental issues. Journal of Hazardous Materials, 23(3), 349.

[15] Achieving sustainable development and promoting development cooperation. (2008). New York: United Nations. https://www.un.org/en/ecosoc/docs/pdfs/fina 08-45773.pdf [Accessed 16 May 2019]. 